\title{
Penerapan Metode Certainty Factor dalam Sistem Pakar Pendeteksi Resiko Osteoporosis dan Osteoarthritis
}

\author{
Stephanie Halim, Seng Hansun \\ Program Studi Teknik Informatika, Universitas Multimedia Nusantara, Tangerang, Indonesia \\ stephaniehalim18@yahoo.co.id, hansun@umn.ac.id
}

Diterima 4 November 2015

Disetujui 10 Desember 2015

\begin{abstract}
Osteoporosis is commonly referred to "thinning" and osteoarthritis referred to "calcification", but people giving wrong action treatment of these two diseases. Therefore, the aim of this study is to develop an android-based application to identify the risk of osteoporosis and osteoarthritis. To identify that risk was processed using certainty factor method. Certainty factor method related about event based on facts, which the source of those facts are from expert and assumed with a value, called certainty factor. From the testing result, the accuracy of this expert system is about $80 \%$.
\end{abstract}

Index Terms-Certainty factor, disease diagnose, expert system, osteoarthritis, osteoporosis

\section{PENDAHULUAN}

Di zaman sekarang ini, perkembangan teknologi sudah sangat cepat. Berbagai aktivitas manusia sudah dimudahkan dengan teknologi, semua dapat dilakukan bahkan apa yang tidak dibayangkan oleh manusia saat ini pun sudah mampu direalisasikan dengan teknologi. Sistem pakar atau expert system juga sudah banyak dikembangkan oleh sejumlah peneliti untuk berbagai bidang, namun yang banyak diimplementasikan adalah kesehatan. Baik manusia, hewan, maupun tumbuhan bisa didiagnosa penyakitnya melalui sistem pakar.

Sistem pakar pada saat ini sudah banyak digunakan manusia, seperti memudahkan masyarakat tanpa harus berkonsultasi dengan dokter atau pakar, bisa mengetahui gejala penyakit lebih dini, atau juga bisa sebagai data pendukung saat berkonsultasi dengan dokter atau pakar terkait sesuai dengan hasil dari sistem pakar tersebut [1]. Salah satu implementasi sistem pakar yang dibangun pada penelitian ini adalah sistem pakar untuk penyakit tulang dan sendi, yaitu penyakit osteoarthritis dan osteoporosis.

Osteoarthritis dan osteoporosis, dua penyakit yang tidak bisa diabaikan walaupun tak banyak orang yang menyadari akan bahayanya dua penyakit ini. Perbedaan kedua penyakit ini adalah osteoarthritis yang dikenal dengan perkapuran yang disebabkan karena pengikisan pada struktur sendi [2], sedangkan osteoporosis adalah pengeroposan pada tulang yang disebabkan karena kurangnya kepadatan tulang [3].

Menurut penelitian yang mencatat data statistik penderita gangguan tulang dan sendi yaitu Ministry of Health dan Arthritis Research UK, bahwa osteoarthritis diderita oleh 875 juta jiwa di seluruh dunia pada tahun 2013 [4], sedangkan osteoporosis pada tahun 2013 juga tercatat 809 juta jiwa di seluruh dunia menderita penyakit ini [5]. Selain itu, kebanyakan masyarakat saat mengeluh sakit pada pinggang atau sendi langsung memilih obat penghilang rasa sakit atau kasus lainnya adalah rutin minum susu yang mengandung kalsium tinggi karena mengganggap di dalam tubuh kekurangan kepadatan tulang padahal pengeroposan dan perkapuran adalah dua penyakit yang berbeda, namun gejalanya hampir mirip sehingga masyarakat terbalik dalam mendiagnosa kedua penyakit ini [3]. 
Dari jumlah angka penderita yang tinggi dan kurangnya kesadaran masyarakat akan perbedaan dua penyakit inilah yang menjadi latar belakang pembangunan sistem pakar untuk mendeteksi resiko penyakit yang diderita masyarakat apakah osteoarthritis atau osteoporosis sehingga masyarakat tidak mengambil tindakan dengan obat yang salah, karena pengobatan yang keliru mungkin dapat mengurangi rasa sakit sementara namun tidak dapat menyembuhkan penyakit.

Sistem pakar ini akan diimplementasikan dengan metode certainty factor. Alasan penggunaan metode ini karena dapat memberikan hasil yang akuratyang didapatkan dari perhitungan berdasarkan bobot gejala yang dipilih pengguna, mampu memberikan jawaban pada permasalahan yang tidak pasti kebenarannya seperti masalah diagnosa resiko penyakit, dan dengan metode ini pakar menggambarkan keyakinan seorang pakar dengan memberikan bobot keyakinan sesuai dengan pengetahuan pakar terkait [6]. Aplikasi akan dibangun dengan berbasis mobile dengan sistem operasi Android. Melihat perkembangan pengguna mobile khususnya Android yang begitu cepat dan meningkat yaitu mencapai angka 1 milyar [7] bahkan meningkat setiap tahunnya sebanyak $40 \%$ per tahunnya [8], sehingga peneliti semakin yakin bahwa sistem pakar ini akan mudah dijangkau dan digunakan oleh masyarakat.

\section{LANDASAN TEORI}

\section{A. Kecerdasan Buatan}

Kecerdasan buatan merupakan ilmu bidang komputer yang mempelajari bagaimana menghasilkan sebuah mesin yang memiliki pikiran dan perilaku yang "cerdas" [9].

Kecerdasan buatan menggabungkan antara sains dengan mesin. Sains, memahami dan mengembangkan teori-teori untuk menjelaskan dan memprediksi sifat dari entitas tersebut, sedangkan mesin sebagai penerapan dari teori- teori tersebut [9].

Adapun fondasi penting dalam kecerdasan buatan yaitu [1]:

a. Philosophy, yaitu logika, metode penalaran, dan pikiran sebagai sistem fisik, dasar pembelajaran, bahasa dan rasionalitas

b. Mathematics, yaitu perhitungan, algoritma, dan formal representasi beserta pembuktian

c. Economics, yaitu teori keputusan yang merupakan kombinasi dari teori probabilitas dengan teori utilitas yang menyediakan sebuah framework yang lengkap untuk pengambilan keputusan

d. Neuroscience, yaitu menggunakan neuron untuk pengolahan informasi

e. Cognitive science, yaitu menggambarkan bagaimana manusia berprilaku, melihat, memproses informasi, serta menggambarkan pengetahuan

f. Computer science, yaitu membangun komputer dengan kualitas yang tinggi dan cepat dalam memproses data

g. Control theory, yaitu merancang sistem dengan maksimal dengan sebuah fungsi objektif

h. Linguistics, yaitu bagaimana sebuah pengetahuan dapat diimplementasikan pada komputer untuk menjadi suatu sistem.

\section{B. Sistem Pakar}

Sistem pakar atau expert system adalah sistem yang mengambil pengetahuan manusia dan memanfaatkannya ke komputer, supaya komputer dapat menyelesaikan masalah layaknya manusia atau yang dilakukan oleh pakar pada umumnya, sehingga sistem pakar dapat menyelesaikan suatu masalah, bahkan

\section{ULTIMA Computing, Vol. VII, No. 2 | Desember 2015}


meniru kerja dari pakar. Sistem pakar pertama kali dikembangkan pada tahun 1960. Sampai sekarang ini banyak sistem pakar yang telah diciptakan, contohnya: mycin, dendral, xcon \& xsel, folio, delta dan masih banyak lagi [9].

Namun, perlu disadari bahwa sistem pakar ini tidak $100 \%$ bernilai benar, paling tidak mendekati nilai tersebut, sehingga sistem pakar ini dapat diandalkan dan menghemat waktu dalam mengambil keputusan [9].

Keuntungan sistem pakar adalah [9]:

1. Dapat memecahkan masalah lebih cepat dari manusia dengan kedalaman data yang sama

2. Menghemat waktu dalam pengambilan keputusan

3. Integrasi sistem pakar dengan komputer lebih efektif dan dapat mencakup aplikasi lebih luas

4. Dapat menyimpan pengetahuan dan keahlian pakar

5. Tidak memerlukan biaya, berbeda jika berkonsultasi dengan dokter atau pakar yang memerlukan biaya

6. Dapat melakukan proses lebih dari satu kali atau berulang

Kriteria sistem pakar adalah [9]:

1. Terbatas pada domain tertentu

2. Dapat memberikan penalaran pada data-data yang bersifat tidak pasti

3. Dapat mengemukakan alasan-alasan yang diberikan dengan cara yang bisa dipahami

4. Dibuat berdasarkan aturan tertentu

5. Pengembangannya secara bertahap

6. Output bersifat saran atau anjuran

Dari penjelasan di atas, sistem pakar bukan pengganti dari para ahli atau pakar tetapi mempermudah masyarakat untuk bertanya dan berkonsultasi dengan pakar, dimana pengetahuan dari pakar diimplementasikan ke dalam sistem pakar tersebut.

\section{Certainty Factor}

Metode certainty factor digunakan ketika menghadapi suatu masalah yang jawabannya tidak pasti. Ketidakpastian ini bisa merupakan probabilitas. Metode ini diperkenalkan oleh Shortlife Buchanan pada tahun 1970-an. Beliau menggunakan metode ini saat melakukan diagnosis dan terapi terhadap penyakit meningitis dan infeksi darah [10]. Tim pengembang dari metode ini mencatat bahwa, dokter sering kali menganalisa informasi yang ada dengan ungkapan seperti "mungkin", "hampir pasti". Metode ini mirip dengan fuzzy logic, karena ketidakpastian direpresentasikan dengan derajat kepercayaan sedangkan perbedaannya adalah pada fuzzy logic saat perhitungan untuk rule yang premisnya lebih dari satu, fuzzy logic tidak memiliki nilai keyakinan untuk rule tersebut sehingga perhitungannya hanya melihat nilai terkecil untuk operator AND atau nilai terbesar untuk operator OR dari setiap premis yang pada rule tersebut berbeda dengan certainty factor yaitu setiap rule memiiki nilai keyakinannya sendiri tidak hanya premis-premisnya saja yang memiliki nilai keyakinan. Certainty factor menunjukkan ukuran kepastian terhadap suatu fakta atau aturan [10].

$$
\mathrm{CF}[\mathrm{h}, \mathrm{e}]=\mathrm{MB}[\mathrm{h}, \mathrm{e}]-\mathrm{MD}[\mathrm{h}, \mathrm{e}]
$$

...(1)

Keterangan :

$\mathrm{CF}[\mathrm{h}, \mathrm{e}]=$ faktor kepastian

$\mathrm{MB}[\mathrm{h}, \mathrm{e}]=$ measure of belief, ukuran kepercayaan atau tingkat keyakinan terhadap hipotesis (h), jika diberikan evidence (e) antara 0 dan 1

$\mathrm{MD}[\mathrm{h}, \mathrm{e}]=$ measure of disbelief, ukuran ketidakpercayaan atau tingkat keyakinan terhadap hipotesis (h), jika diberikan evidence (e) antara 0 dan 1 . Adapun beberapa kombinasi certainty factor terhadap premis tertentu:

1. Certainty factor dengan satu premis.

$$
\mathrm{CF}[\mathrm{h}, \mathrm{e}]=\mathrm{CF}[\mathrm{e}] * \mathrm{CF}[\text { rule }]
$$


$=\mathrm{CF}[$ user $] * \mathrm{CF}[$ pakar $]$

1. Certainty factor dengan lebih dari satu premis.

$\mathrm{CF}[\mathrm{A} \wedge \mathrm{B}]=\operatorname{Min}(\mathrm{CF}[\mathrm{a}], \mathrm{CF}[\mathrm{b}]) * \mathrm{CF}[$ rule $] \ldots(3)$

$\mathrm{CF}[\mathrm{A} \vee \mathrm{B}]=\operatorname{Max}(\mathrm{CF}[\mathrm{a}], \mathrm{CF}[\mathrm{b}]) * \mathrm{CF}[$ rule $] \ldots(4)$

2. Certainty factor dengan kesimpulan yang serupa.

$\mathrm{CF}_{\text {gabungan }}[\mathrm{CF} 1, \mathrm{CF} 2]=\mathrm{CF} 1+\mathrm{CF} 2 *(1-\mathrm{CF} 1) \quad \ldots(5)$

Kelebihan dari metode ini adalah cocok digunakan pada sistem pakar yang mengukur sesuatu yang pasti atau tidak pasti seperti mendiagnosis penyakit dan perhitungan dari metode ini hanya berlaku untuk sekali hitung, serta hanya dapat mengolah dua data sehingga keakuratannya terjaga [6].

\section{Osteoporosis}

Osteoporosis adalah penyakit yang disebabkan karena massa pada tulang yang sudah berkurang atau rendah, serta gangguan pada mikro arsitektur tulang dan penurunan jaringan tulang, yang menimbulkan kerapuhan tulang. Kekuatan tulang merefleksikan gabungan dari dua faktor, yaitu densitas tulang dan kualitas tulang [3].

Tulang adalah jaringan yang hidup dan terus bertumbuh. Tidak hanya memberikan kekuatan dan membuat kerangka tubuh menjadi stabil, tulang juga terus mengalami perubahan karena berbagai stres mekanik dan terus mengalami pembongkaran, perbaikan dan pergantian sel. Berkurangnya massa tulang terjadi setelah 30 tahun, yang akan terus berkurang sehingga inilah yang menyebabkan terjadinya pengeroposan pada tulang atau osteoporosis [3].

Selain faktor berkurangnya massa tulang, penyebab lain dari osteoporosis adalah mengonsumsi beberapa macam obat-obatan dalam jangka panjang yang dapat merusak tulang seperti obat anti kejang dan hormon tiroid yang diresepkan dalam dosis tinggi, dan terganggunya proses penyerapan kalsium, serta cushing yaitu produksi kortisol tubuh yang berlebihan [3].

\section{E. Osteoarthritis}

Osteoarthritis (OA) adalah kelainan degradasi sendi, termasuk tulang rawan articular dan tulang subchondral. Manifestasi dari penyakit ini adalah nyeri pada sendi, nyeri tekan, kekakuan, berderit, penguncian sendi, dan kadang-kadang peradangan lokal. Penyakit ini mengenai sendisendi besar, terkadang dapat mengenai sendisendi kecil pada tangan dan kaki. Biasanya disebut dengan pengapuran [2].

Osteoarthritis terjadi dalam dua pola [2]:

1. OA primer, terjadi pada laki-laki usia pertengahan dan pada wanita usia lebih tua (dialami setelah usia 45 tahun), menyerang secara perlahan tapi progresif, dan dapat mengenai lebih dari satu persendian. Biasanya menyerang sendi pada berat badan seperti lutut, panggul, menyerang punggung, leher, serta jari-jari.

2. OA sekunder, terjadi pada setiap usia dan abnormal sejak lahir (dialami sebelum usia 45 tahun), biasanya disebabkan karena trauma yang menyebabkan luka pada sendi seperti patah tulang atau permukaan sendi tidak sejajar, akibat sendi yang longgar, dan pembedahan pada sendi. Perubahan yang paling mencolok dari osteoarthritis biasanya terdapat di daerah tulang rawan yang mendapat beban pada stadium awal, tulang rawan lebih tebal daripada normal, tetapi seiring dengan perkembangan $\mathrm{OA}$ permukaan sendi menipis, tulang rawan melunak, integritas permukaan terputus dan terbentuk celah vertikal [2].

III. RANCANGAN ALUR KERJA DAN TAMPILAN ANTARMUKA APLIKASI

\section{A. Rancangan Alur Kerja Aplikasi}

Alur dari aplikasi sistem pakar ini, terdiri

\section{ULTIMA Computing, Vol. VII, No. 2 | Desember 2015}


dari beberapa menu seperti menu periksa, menu info penyakit, info dokter, feedback, dan about. Yang menjadi tujuan utama dari penelitian ini terdapat pada menu periksa karena pada menu ini dilakukan implementasi penggunaan metode certainty factor untuk menentukan resiko penyakit pada pengguna apakah pengguna memiliki resiko penyakit osteoporosis atau penyakit osteoarthritis. Selain penentuan resiko penyakit, pemberian solusi untuk pengguna juga tersedia karena sebagai aplikasi sistem pakar salah satu syaratnya ialah memberikan solusi kepada penggunanya setelah penentuan resiko penyakit telah ditentukan diagram alir untuk proses ini akan dijelaskan pada bagian berikunya. Bukan hanya menu periksa namun setiap menu-menu yang ada pada aplikasi sistem pakar ini seperti menu info penyakit untuk melihat informasi secara detail tentang penyakit osteoporosis dan penyakit osteoarthritis, info dokter untuk melihat informasi mengenai dokter yang menangani kedua penyakit atau dokter spesialis internist (penyakit dalam), feedback untuk memberikan tanggapan layaknya mengisi sebuah kuesioner secara manual, dan about untuk memberikan informasi mengenai aplikasi sistem pakar ini. Diagram alir untuk aplikasi secara keseluruhan atau menu utama dijelaskan pada gambar 1. Diagram ini juga menggambarkan bagaimana rancangan navigasi untuk menu utama dari aplikasi sistem pakar selain nama menumenu yang akan digunakan pada aplikasi sistem pakar untuk menentukan resiko osteoporosis dan osteoarthritis dengan metode certainty factor berbasis Android ini. Di bawah ini gambar 1, yang merupakan gambar diagram alir aplikasi menu utama.

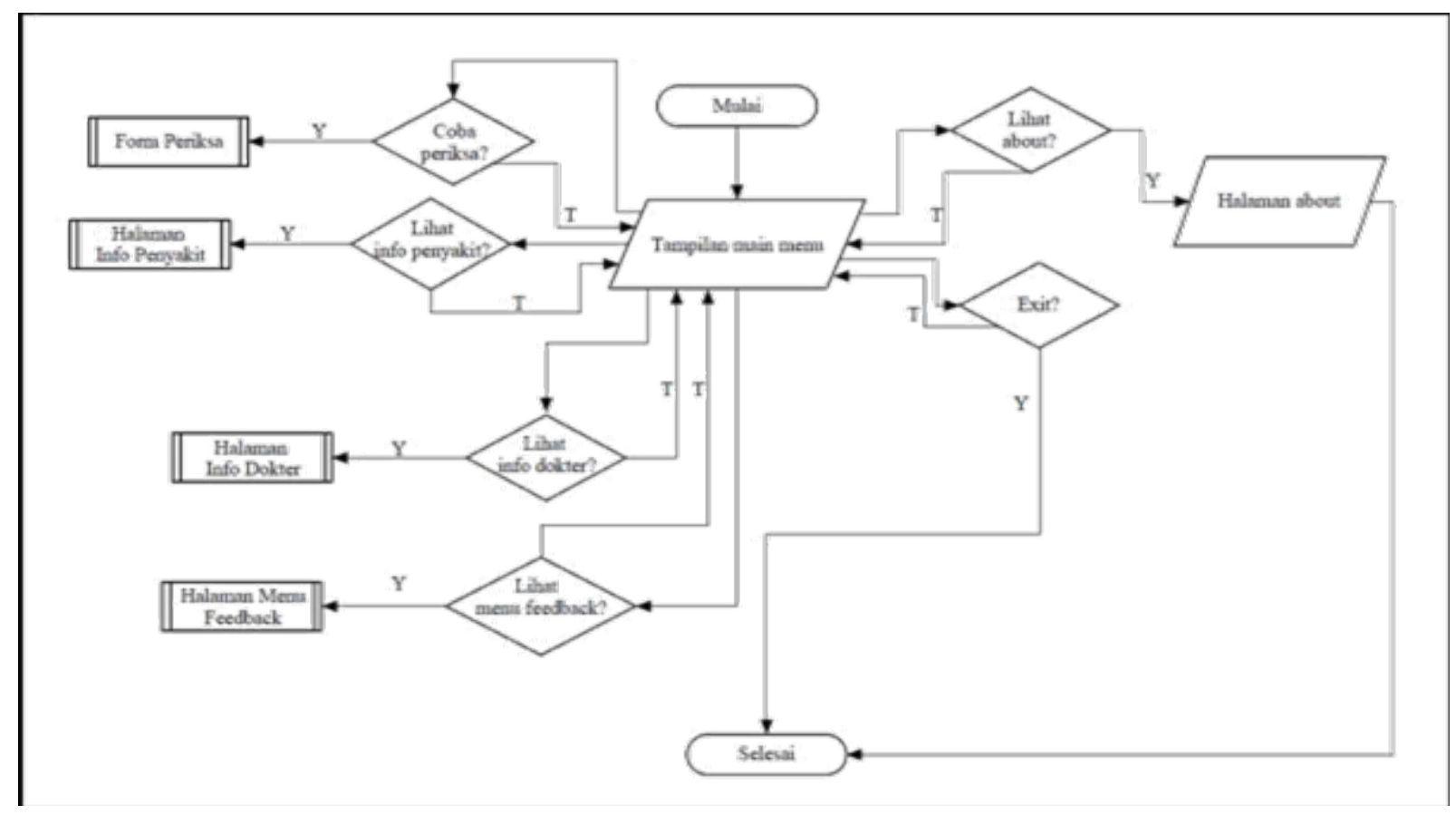

Gambar 1. Diagram alir aplikasi menu utama 


\section{A.1 Prosedur Periksa}

Pada prosedur atau menu ini, pengguna akan menjawab sejumlah pertanyaan dan juga beberapa daftar gejala sesuai dengan apa yang dirasakan pengguna, setelah itu proses perhitungan dengan menggunakan rumus metode certainty factor. Pada aplikasi ini rumus menghitung premis dengan kesimpulan serupa, CFgabungan[CF1,
$\mathrm{CF} 2]=\mathrm{CF} 1+\mathrm{CF} 2 *(1-\mathrm{CF} 1)$. Setiap perhitungan hanya dapat memproses dua buah data sehingga jika lebih dari dua data dilakukan perulangan untuk mendapatkan nilai certainty factor untuk setiap penyakit. Gambar 2 merupakan diagram alir bagaimana proses perhitungan setiap penyakit untuk menentukan resiko penyakit yang diderita oleh pengguna.

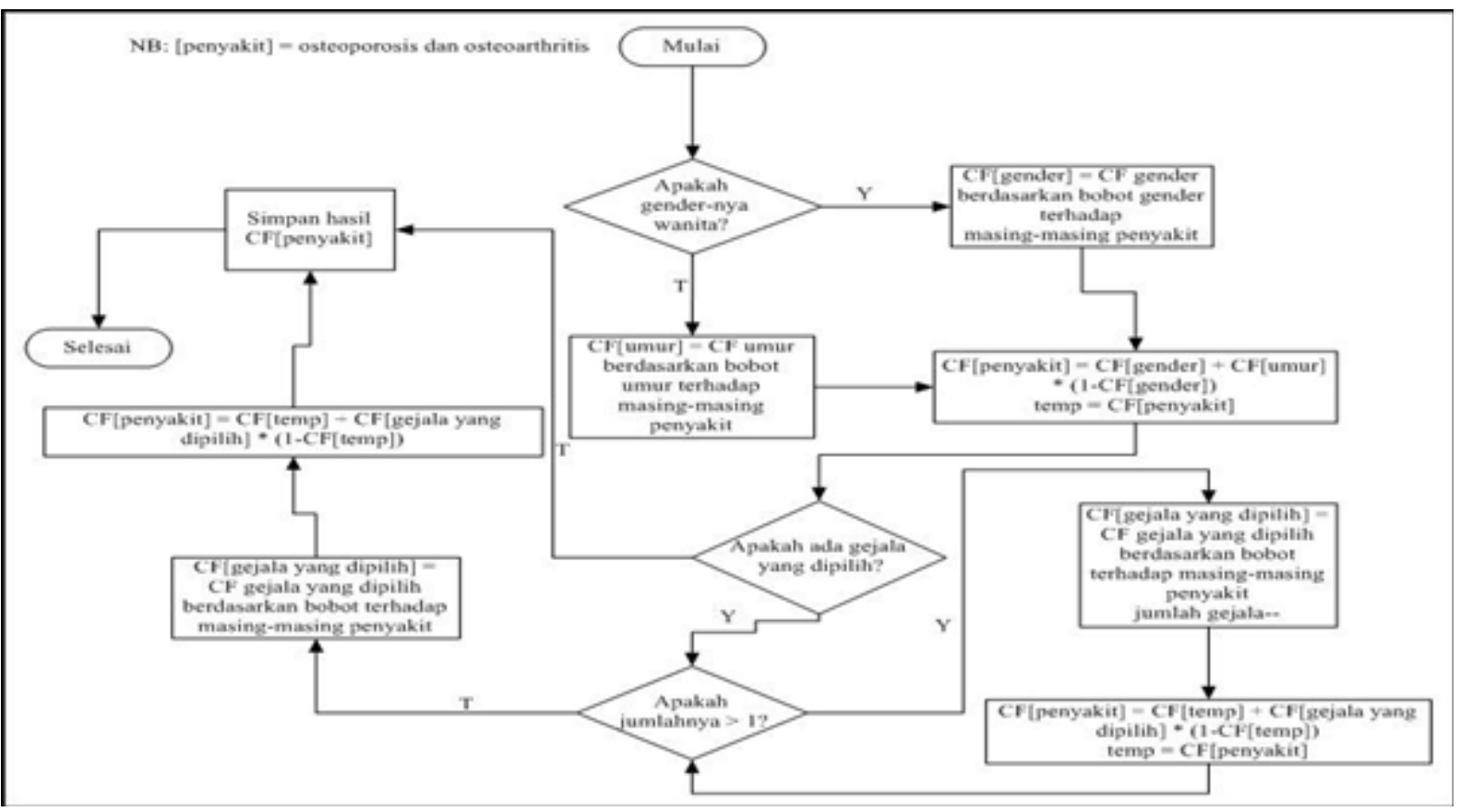

Gambar 2. Diagram alir proses perhitungan

Selanjutnya, setelah didapatkan nilai certainty factor setiap penyakit, kedua nilai tersebut akan dibandingkan untuk mencari nilai terbesar. Nilai yang paling besar menjadi resiko penyakit yang diderita oleh pengguna. Untuk menentukan solusi yang akan diberikan pengguna dapat dilakukan dengan setelah mendapatkan resiko penyakit yang diderita maka solusi akan diberikan berdasarkan hasil resiko penyakit yang telah ditentukan dari proses sebelumnya.

\section{A.2 Prosedur Info Penyakit}

Prosedur ini menjelaskan secara detail mengenai penyakitosteoporosis dan osteoarthritis seperti pengertian penyakit tersebut, alasan terjadinya, pencegahan penyakit, dan pengobatan kedua penyakit tersebut.

\section{A.3 Prosedur Info Dokter}

Selain info penyakit, aplikasi ini juga memberikan menu atau prosedur info dokter untuk melihat dokter-dokter mana saja yang bisa dihubungi untuk perihal konsultasi atau pengobatan lebih lanjut. Data-data dokter yang disediakan pada aplikas ini adalah dokter penyakit dalam yang bisa dikatakan sebagai pakar untuk penyakit osteoporosis dan osteoarthritisi. Datadata dokter yang ditampikan berupa nama dokter, tempat praktek, alamat tempat praktek, jam 
praktek, nomor telepon, dan e-mail.

Data-data dokter tersebut ditampilkan dengan menggunakan pemanfaatan database di dalamnya.

\section{A.4 Prosedur Feedback}

Dengan prosedur ini, pengguna dapat memberikan tanggapan terhadap aplikasi sistem pakar ini, bisa dikatakan prosedur ini sebagai kuesioner bagi para pengguna yang biasanya dilakukan secara manual, tetapi pada aplikasi ini kegiatan tersebut diubah menjadi secara terkomputerisasi sehingga pengguna merasa lebih mudah untuk memberikan tanggapan atau komentar. Penyimpanan jawaban setiap pengguna disimpan menggunakan database dan peneliti juga dapat melihat jawaban pengguna untuk dokumentasi penelitian melalui database.

\section{A.5 Prosedur About}

Prosedur ini memberikan penjelasan singkat mengenai aplikasi ini dan memberikan informasi kepada pengguna bahwa aplikasi ini telah divalidasi oleh dokter rumah sakit sehingga dapat menambah kepercayaan pengguna terhadap hasil yang diberikan oleh aplikasi sistem pakar ini.

\section{B. Rancangan Tampilan Antarmuka Aplikasi}

Rancangan tampilan antarmuka aplikasi diberikan pada gambar 3 memberikan aplikasi halaman menu utama pada aplikasi sistem pakar ini, pada halaman menu utama berisi menu-menu yang dapat dipilih oleh user seperti menu periksa, menu info penyakit, menu info dokter, menu feedback, menu about, dan juga terdapat button exit untuk keluar dari aplikasi sistem pakar ini. Gambar rancangan tersebut dibuat dengan menggunakan rancangan mock up.

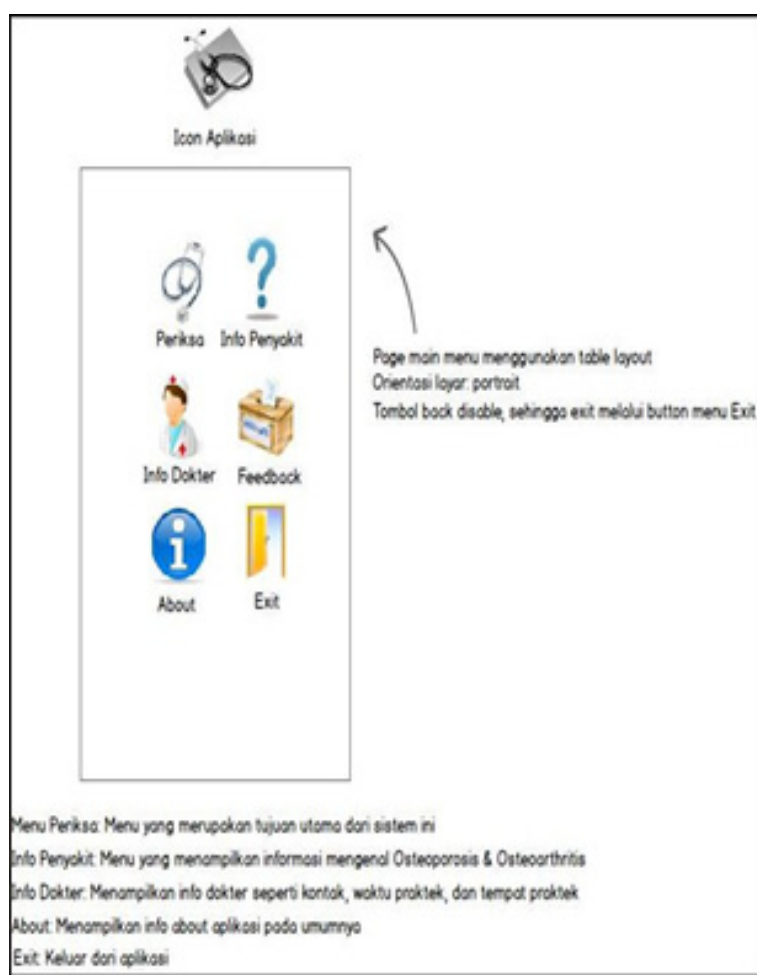

Gambar 3. Rancangan mock up menu utama

Selanjutnya, menjadi tujuan utama penelitian ini yaitu menu periksa. Rancangan mock up menu periksa dijelaskan pada gambar di bawah ini.

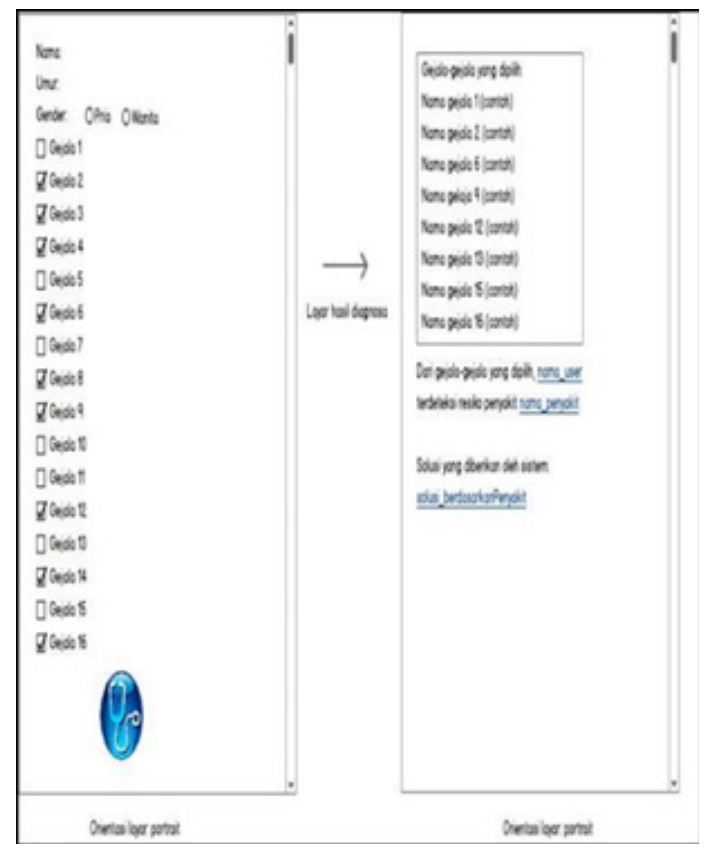

Gambar 4. Rancangan mock up menu periksa 


\section{PENELITIAN DAN HASILNYA}

\section{A. Tabel Gejala dan Solusi}

Tabel gejala beserta dengan bobot didapatkan dari wawancara dengan pakar atau dokter rumah sakit yang digunakan sebagai daftar pertanyaan menu periksa dan bobotnya sebagai data yang akan dihitung untuk mencari nilai certainty factor setiap penyakit. Karena setiap gejala memiliki angka bobot yang berbeda terhadap masingmasing penyakit sehingga apabila dihitung nilai dari masing-masing penyakit akan berbeda hasilnya. Tabel 1 merupakan screen shot dari tabel gejala.

Tabel 1. Tabel Gejala

\begin{tabular}{|c|l|c|c|}
\hline No. & \multicolumn{1}{|c|}{ Gejala } & Osteoporosis & Osteoarthritis \\
\hline 1 & Jarang mengonsumsi makanan yang mengandung vit D seperti tahu, ikan, susu & 0.6 & 0.2 \\
\hline 2 & Pernah mengalami patah tulang & 0.8 & 0.6 \\
\hline 3 & Kurang banvak bergerak (berialan kaki atau olahraga) & 0.8 & 0.3 \\
\hline 4 & Nyeri pada sendi pada kedua sisi tubuh (lokasi nyeri dapat dituniukkan dengan jelas) & 0 & 0.8 \\
\hline 5 & Nyeri.pada sendi pada kedua sisi tubuh (lokasi nyeri tidak dapat ditunjukkan dengan jelas) & 0.8 & 0 \\
\hline 6 & Kekakuan pada sendi (biasa teriadi pada pagi hari atau bangun tidur) & 0 & 0.8 \\
\hline 7 & Pembengkakkan pada sendi & 0 & 0.6 \\
\hline 8 & Kehilangan kelenturan pada sendi (susah untuk menggerakkan badan dengan bebas) & 0 & 0.8 \\
\hline 9 & Cacat atau disabilitas & 0 & 0.8 \\
\hline 10 & Saat naik tangga, terdengar bunvi pada lutut & 0 & 0.8 \\
\hline 11 & Ada turunan mengalami osteoarthritis & 0 & 0.8 \\
\hline 12 & Jenis kelamin: wanita & 0.8 & 0.8 \\
\hline 13 & Kelebihan berat badan (gemuk) & 0.3 & 0.6 \\
\hline 14 & Rematik atau encok & 0.3 & 0.6 \\
\hline 15 & Usia di atas 45 tahun / jika di bawah 45 tahun & $0.6 /-0.6$ & $0.6 /-0.6$ \\
\hline
\end{tabular}

Tabel 2 merupakan tabel solusi yang juga didapatkan dari hasil wawancara dengan pakar.

Tabel 2. Tabel solusi

\begin{tabular}{|c|c|}
\hline Nama Renyakit & Solusi \\
\hline \multirow[b]{3}{*}{ Osteoporosis } & - Rutin berolahraga \\
\hline & - Banyak bergerak daripada banvak duduk \\
\hline & $\begin{array}{l}\text { - Untuk obat, harus konsultasi dengan dokter } \\
\text { karena ada faktor-faktor yang barus diperhatikan seperti dosis obat, faktor diabetes, efek samping, } \\
\text { dan lain- dan lain-lain }\end{array}$ \\
\hline \multirow[b]{2}{*}{ Osteoarthritis } & - Bagian yang terasa nyeri diistirahatkan \\
\hline & $\begin{array}{l}\text { - Untuk obat, ada tahap } 1 \text { sampai } 5 \\
\text { Tahap } 1 \text { : minum obat yang dijual secara umum } \\
\text { untuk penahan rasa sakit seperti panadol atau parasetamol } \\
\text { Tahap } 2 \text { sampai } 5 \text { barus pengobatan melalui dokter secara intensif } \\
\text { (obat-obatan harus melalui resep dokter) } \\
\text { - Kensultasi dengan dokter terkait untuk pencegahan rasa nveri lebih laniut }\end{array}$ \\
\hline
\end{tabular}




\section{B. Pengujian Fungsionalitas}

Pada bagian ini menjelaskan bagaimana perhitungan dilakukan saat pengguna sudah mengisi daftar pertanyaan dan gejala pada menu periksa. Di bawah ini merupakan contoh perhitungan manual yang prosesnya sama seperti aplikasi sistem pakar ini bekerja.

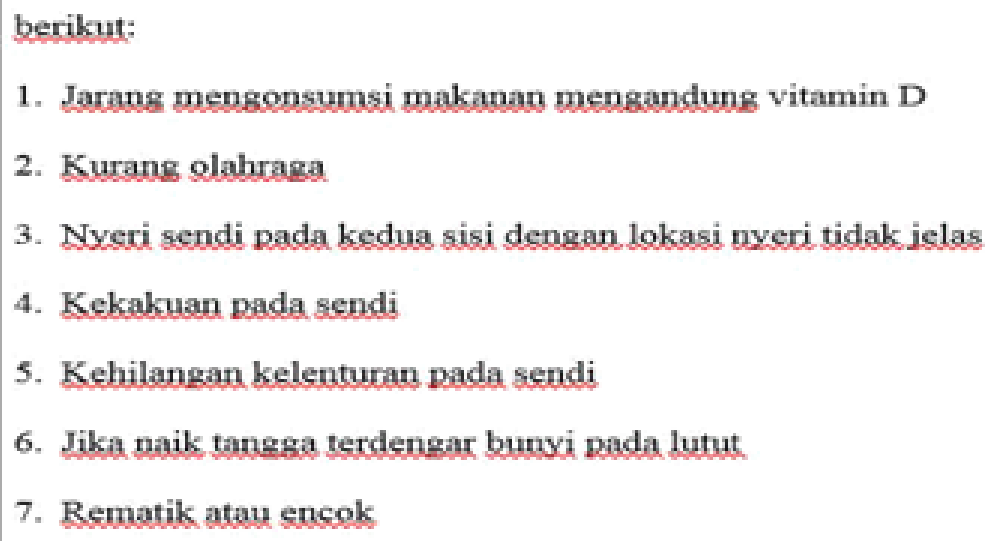

1. Jarang mengonsumsi makanan mengandung vitamin $D$

2. Kurang olahraga

3. Nyeri sendi pada kedua sisi dengan lokasi nyeri tidak ielas

4. Kekakuan pada sendi

5. Kehilangan kelenturan pada sendi

6. Jika naik tangga terdengar bunxi pada lutut

7. Rematik atau encoks

Gambar 5. Contoh kasus perhitungan

Gambar berikutnya contoh perhitungan untuk mencari certainty factor osteporosis berdasarkan contoh kasus pada gambar 5 .

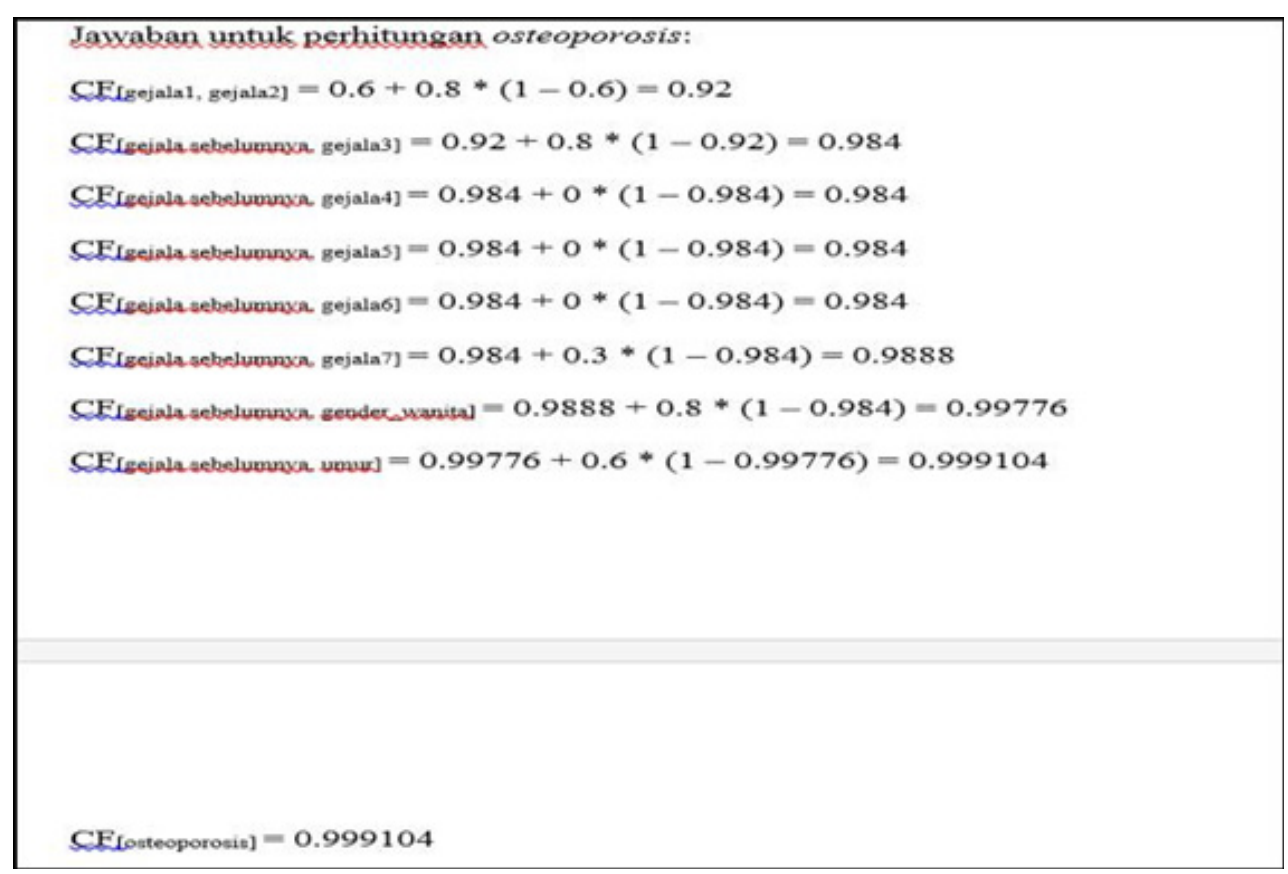

Gambar 6. Perhitungan certainty factor osteoporosis 
Gambar 7, berisi perhitungan certainty factor untuk penyakit osteoarthritis yang prosesnya sama dengan gambar 6 namun berbeda penyakit dan data bobot yang dimasukan dalam proses perhitungan.

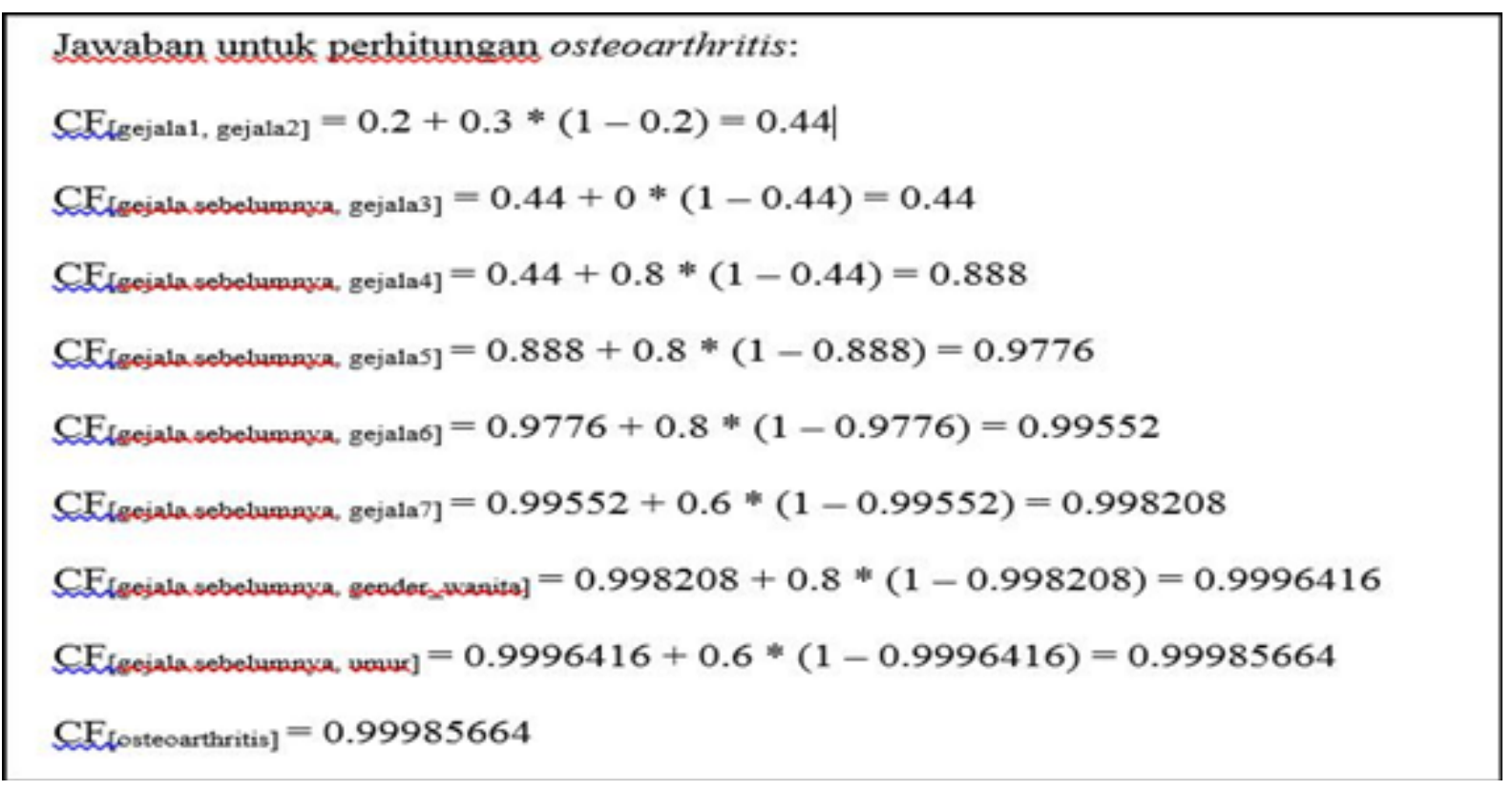

Gambar 7. Perhitungan certainty factor osteoarthritis

Dari hasil perhitungan pada dua gambar terakhir, dapat disimpulkan bahwa wanita tersebut terdeteksi resiko penyakit osteoarthritis karena nilai certainty factor osteoarthritis lebih besar dari nilai certainty factor osteoporosis.

\section{Rekapitulasi Sampel Data}

Berikut rekapitulasi sampel data yang melibatkan 32 orang dengan 30 orang yang koresponden yang juga mengisi kuesioner sedangkan 2 orang lainnya adalah sampel data untuk penelitian. Hasil rekapitulasi dari seluruh sampel data tersebut.
Tabel 3. Rekapitulasi Sampel Data

\begin{tabular}{|c|c|c|}
\hline No. & Hasil diagnosa resiko & Jumlah orang \\
\hline 1. & Osteoporosis & 5 \\
\hline 2. & Osteoarthritis & 12 \\
\hline 3. & Bukan kedua penyakit & 14 \\
\hline 4. & Kedua penyakit & 1 \\
\hline
\end{tabular}

\section{Rekapitulasi Validasi Sistem Melalui Pakar}

Setelah sampel data dikumpulkan, sebagian dari sampel data tersebut dibawa kepada dokter spesialis dalam untuk diuji keakuratannya. Pada penelitian ini melibatkan dua orang dokter dengan spesialis yang sama namun berbeda rumah sakit. Hasil dari pengujian tersebut Dokter Edi Karwono (dokter spesialis penyakit dalam rumah sakit Omni) sebagai dokter yang memberikan data gejala beserta nilai bobot menguji aplikasi ini dan presentase keakuratannya adalah 100\% 
sedangkan dokter Budi Wijaya (dokter spesialis penyakit dalam rumah sakit St. Carolus) memberikan presentase keakuratan aplikasi ini sebesar $60 \%$ sehingga jika dirata-rata keakuratan aplikasi ini mencapai 80\%. Perbedaan presentase keakuratan ini terjadi karena perbedaan kedua pakar berdasarkan history dan skill sebagai dokter.

\section{SIMPULAN}

Implementasi metode certainty factor untuk aplikasi sistem pakar mendeteksi resiko penyakit osteoporosis dan osteoarthritis berhasil diimplementasikan. Dengan presentasikeakuratan $80 \%$ menjadi bukti nyata bahwa diagnosa gejala setiap pakar mempengaruhi tingkat keakuratan sistem sehingga untuk menghindari hal ini jika melibatkan lebih dari satu pakar, pakar-pakar tersebut harus mendiskusikan gejala yang tepat bagi pakar-pakar tersebut sehingga keakuratan sistem memiliki presentase yang lebih baik. Pada penelitian ini, untuk daftar gejala hanya melibatkan satu orang pakar, sedang satu pakar lainnya hanya sebagai penguji tambahan terhadap proses validasi aplikasi ini.

\section{Daftar Pustaka}

[1] Russel, S., dan Norvig, P. 2010. Artifical Intelligence: A Modern Approach, $3^{\text {rd }}$ Edition. New Jersey: Pearson Education.

[2] Moskowitz, R., Altman, R., Buckwalter J., and Goldberg. 2007. Ostheoarthritis: Diagnosis and Medical/Surgical Management Fourth Edition. USA: Lippimcott Willams \& Wilkins.

[3] Tandra, Hans. 2009. Segala Sesuatu Yang Harus Anda Ketahui Tentang Osteoporosis Mengenal, Mengatasi, dan Mencegah. Jakarta: Gramedia Pustaka Utama.

[4] Arthritis Research UK. 2013. Osteoarthritis in General Practice (Data and Perspectives). England and Wales: Arthritis Research UK.

[5] Ministry of Health. 2013. World Osteoporosis
Day 2013 [online]. Tersedia dalam: http://www. moh.gov.sa/en/HealthAwareness/healthDay/201 3/Pages/HealthDay-025.aspx [diakses 23 Desember 2014].

[6] Turban, E., dan Aronson, J.E. 2001. Decision Support System and Intelligent System, 6th Edition. New Jersey: Prentice Hall International Edition.

[7] Chip Online. 2013. Selama 5 Tahun, Pengguna Android Mencapai 1 Miliar [online]. Tersedia dalam: http://www.chip.co.id/news/ web_internet-software_os- gadget-androidtechnology/8793/selama_5_tahun_pengguna_ android_menca pai_1_miliar [diakses 23 Desember 2014].

[8] Tribun News. 2012. Jumlah Pengguna Android Naik 40\% per Tahun [online]. Tersedia dalam: http://www.tribunnews.com/bisnis/2012/11/16/ jumlah- pengguna-android-naik-40-per-tahun [diakses 23 Desember 2014].

[9] Kusumadewi, S. 2003. Artifical Intelligence (Teknik dan Aplikasinya). Yogyakarta: Graha Ilmu.

[10] Daniel dan Virginia, G. 2010, Implementasi Sistem Pakar Untuk Mendiagnosis Penyakit Dengan Gejala Demam Menggunakan Metode Certainty Factor. Jurnal Informatika. 6, (1), 2636. 